AJAR

6,2

\section{6}

Received 13 July 2020

Revised 6 October 2020 20 November 2020

Accepted 1 December 2020

\title{
Independence from the perspective of the Shari'ah committee
}

\author{
Nor Hafizah Zainal Abidin and Fatimah Mat Yasin \\ Department of Accounting, International Islamic University Malaysia, \\ Kuala Lumpur, Malaysia, and \\ Ahmad Zainal Abidin \\ Zurich Takaful Malaysia Berhad, Kuala Lumpur, Malaysia
}

\begin{abstract}
Purpose - The purpose of this study is to gather the perceptions of the Shari'ah committee members on what and how they safeguard and strengthen their independence in fact and independence in appearance during the discharge of their duties.

Design/methodology/approach - Data were gathered through semi-structured interviews with 13 Shariah committee members from 13 different Islamic financial institutions (IFIs).

Findings - Based on the Islamic worldview and agency theory, the findings suggest that safeguard measures within the context of the Shariah committee are strengthened by the following factors: presence of competencies, personal characteristics of the Shariah committee members, board engagement, role of the chairman in the Shari'ah committee and accountability to God. Based on the agency theory, it can be suggested that the characteristics of the Shariah committee and the presence of an effective governance structure are able to minimise threats to the independence of the Shari'ah committee and enhance its effectiveness.

Practical implications - The insights from this study highlight that proper and fit criteria need to be enhanced to ensure the independence of the Shariah committee members when performing their roles for IFIs. Moreover, it shows that board engagement and chairman involvement in overseeing the Shari'ah committee in the discharge of its duties is able to improve the independence of the Shari'ah committee both in fact and in appearance.

Originality/value - This study contributes to the evidence on safeguard measures in the Malaysian context, which is highly regulated in relation to the Shariah governance practices in IFIs. This evidence could be considered by other Shariah committees in different contexts.
\end{abstract}

Keywords Shari'ah committee, Independence, Role, Competence, Safeguard

Paper type Research paper

\section{Introduction}

Shari'ah governance is integral to the stability of the Islamic financial system. It strengthens the confidence of stakeholders and the public in the activities and operations of Islamic financial institutions (IFIs). The Shari'ah committee generally performs a critical function in the Shari'ah governance of IFIs. The role of the Shari'ah committee is strengthened by its provision of objective and quality Shari'ah advice and decisions. Furthermore, independence is deemed to be a crucial criterion in determining the ability of an individual to make sound, unbiased and informed judgements (BNM, 2010, 2019). Therefore, based on the findings of prior studies by Al Mannai and Ahmed (2018) and Haridan et al. (2018), the reliance of the

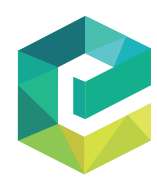

(C) Nor Hafizah Zainal Abidin, Fatimah Mat Yasin and Ahmad Zainal Abidin. Published by Emerald Publishing Limited. This article is published under the Creative Commons Attribution (CC BY 4.0) licence. Anyone may reproduce, distribute, translate and create derivative works of this article (for both commercial and non-commercial purposes), subject to full attribution to the original publication and authors. The full terms of this licence may be seen at http://creativecommons.org/licences/by/4.0/ legalcode

Financial assistance for this study was kindly contributed by Bank Pembangunan Malaysia Berhad Research

Vol. 6 No. 2, 2021

pp. 196-209

Emerald Publishing Limited 2443-4175

DOI 10.1108/AJAR-07-2020-0053 (BPMB) (Grant no: SP19-014-0433). The authors would like to thank reviewers and all participants that contributed great insights and constructive comments. 
Shariah committee on the internal compliance unit in providing independence assurance should be scrutinised critically in order to ensure that any conflict of interest is avoided. In addition, the independence of the Shari'ah committee is also at stake due to its reliance on remuneration and renewal terms that are determined by IFIs. Thus, the establishment of a clearly independent Shariah committee is vital to assure the credibility of Shariah compliance practices and investor confidence in IFIs. Moreover, in line with the accountability theory, the Shari'ah committee ought to concentrate on maximising the performance of IFIs for the benefit of society, whereas, according to agency theory, it ought to merely focus on maximising the returns for shareholders (Alnasser and Muhammed, 2012). Therefore, this study aims to gather the perceptions of the Shari'ah committee members on issues related to their level of independence, the safeguard measures that are currently in place and any additional ones that are needed to strengthen their independence in fact and independence in appearance when performing their oversight duties.

This study contributes to the literature in several ways. First, while most of the literature has extensively discussed the issue of independence, it has done so in the context of the challenges Shari'ah committee members face in performing their duties effectively (Garas, 2012; Haridan et al., 2018; Hassan, 2012; Kassim et al., 2016; Mohamad et al., 2015; Ullah et al., 2016). Yet, in reality, little is known about the day-to-day issues that impair the independence in appearance and independence in fact of the Shari' ah committee. Therefore, this study explores the practical reality of the situations or circumstances that could hamper the independence of the Shariah committee. Second, prior studies have been mostly conceptual, proposing frameworks for the discussion of the challenges faced by Shariah committee members in discharging their duties effectively (Mohamad et al., 2015; Kassim et al., 2016; Haridan et al., 2018). Hence, little is known about the safeguard measures that are practised by the Shariah committee in order to address issues that threaten their independence. Thus, this study complements the study of Sori et al. (2015), which discussed the importance of the independence of the Shari'ah committee, by providing further evidence on how the committee safeguards and strengthens its independence in fact and independence in appearance in the practice of its duties. The findings provide an in-depth insight into the inward perspective of the respondents, which were qualitatively derived, with regard to the practical reality of the issues they face and the safeguard measures exercised by them to overcome and minimise the challenges encountered in fulfilling their role. Third, this study was conducted in Malaysia, a country that implements a two-tier and centralised model of Shari'ah governance and is widely known as having an enhanced regulatory environment for IFIs (Mohamad and Sori, 2016). Other studies have focused on other widely different jurisdictions in terms of the economic, political, cultural, religious, ideological and historical contexts in which regulations are framed within which IFIs operate. Thus, the insights into this study in the Malaysian context could point to some good practices that could be employed by other jurisdictions particularly in relation to the adoption of proper and fit criteria for members of Shariah committee in particular.

Based on the preceding arguments, the problem of how to safeguard against the impairment of the independence of the Shari'ah committee has received little attention from the research community. While some issues have been extensively discussed, a greater focus on practical solutions and definitive outcomes is also crucial in order to overcome the challenges facing the Shariah committee in the fulfilment of its responsibilities. Hence, this study aims, first, to examine the actual issues that impair the independence of the Shariah committee. Second, through semi-structured interviews, it aims to gather first-hand information from the Shariah committee members themselves on the safeguard measures that are exercised to realise the upholding of their independence in fact and independence in appearance. The next section of this paper briefly outlines the findings in the literature on the Shari'ah Governance Framework 2010 (SGF 2010) and Shariah Governance Policy Document 2019 (SGPD 2019) in Malaysia and the issues related to the independence of the
Independence of the Shari'ah committee 
AJAR

6,2

Shariah committee more generally. This is followed by a section that describes the methodology employed in this study and a section that discusses the findings of the research. The last section of this paper concludes the paper by highlighting the implications of the study and making some suggestions for further research.

\section{Literature review}

Malaysia in general practises a two-tier or centralised model of Shari'ah governance, which comprises two vital components, namely, the Shari'ah Advisory Council (SAC), which advises Bank Negara Malaysia (BNM), and the Shari'ah committee, which is found in every IFI. The $\mathrm{SAC}$ is the ultimate authority on Islamic finance operations and activities, whereas the Shari'ah committee is mandated to provide guidance on Shari'ah matters to its respective IFI (Mohamad and Sori, 2016). Overall, the Shari'ah governance of IFIs in Malaysia is administered in accordance with the BNM Act, 2009, the Islamic Financial Services Act 2013 and the latest SGPD 2019 (the revised version of SGF 2010). According to SGF 2010, the board of directors is the ultimate oversight mechanism in IFIs. It is supported by the presence of the Shariah committee in its task of monitoring Shari'ah compliance in IFIs. Other control functions include Shari'ah review, Shari'ah research, Shari'ah audit and Shari'ah risk management. Then, in 2019, due to the growing business complexity of IFIs, the SGPD was issued to provide greater clarity on the roles of Shariah committee members to ensure the independent and effective discharge of their duties. In particular, the new SGPD 2019 framework spells out some additional, new requirements that Shariah committee members must observe in providing objective decisions and sound advice to IFIs. These new requirements, among others, stipulate that Shari'ah committee members can no longer serve a single IFI for more than nine years (this ruling will be applicable from April 2023) in order to ensure their professional independence and objectivity. In addition, SGPD 2019 disallows any active politicians from being Shariah committee members. The new framework also requires the boards of directors of IFIs to establish effective communication with Shari'ah committee members to ease discussion of all Shariah matters and enable both parties to discharge their roles and responsibilities effectively. In a similar vein, SGPD 2019 also addresses the issue of the independence of Shariah committee members, which should not be affected by multiple appointments and other professional commitments that may give rise to conflicts of interest. Likewise, they are also required to allocate sufficient time to prepare for and attend meetings. Moreover, Shari'ah committee members are expected to keep abreast of recent developments in the industry because this may enhance their decision-making process in arriving at an informed judgement. Finally, the chairman of the Shari'ah committee is also required to play certain roles in the deliberation process during meetings to ensure that Shariah committee members can express and discuss Shari'ah matters and issues freely. In short, the SGPD 2019 framework indicates that the independence of Shariah committee members is one of the essential elements in determining the quality of Shari'ah assurance. Hence, members of the committee must be able to make objective judgements and informed decisions without being subject to any undue influence because they are accountable for all the advice and decisions they make. Moreover, the Shari'ah committee considers the interests of shareholders or maslahah of ummah as required by the Maqasid, which could enhance public trust and confidence.

\subsection{Insights from prior studies}

Shariah governance divinely originates from the Quran and Sunnah, which define the ordained guidelines of Muslim conduct in all aspects of life including financial matters. Specifically, it concerns the maslahah of ummah and prescribes that all forms of transaction, financial or otherwise must be free of any elements of injustice to the transacting parties 
(Mohamad et al., 2015). Implicitly, Shari'ah governance requires that all parties are accountable for their assigned responsibilities to all mankind. In contrast, the concept of corporate governance in the western context relates to guidelines that are designed to help manage a corporation effectively to achieve its objectives and these guidelines give greater emphasis to robust performance, transparency, fairness and accountability in the interest of capital providers. The agency theory underlines that presence of independence is to overcome conflicts of interest and information asymmetry in managing the interests of shareholders (Mohammed and Muhammed, 2017). On the other hand, corporate governance from the Islamic perspective is concerned more with the maslahah of Shariah compliance for the benefit of society as a whole, which is achieved through the oversight duties that are undertaken by the Shari'ah committee (Mohammed and Muhammed, 2017). Both of these governance concepts uphold similar attributes of transparency and accountability, but Shari'ah governance has an added value of focussing on the interests of and justice for all stakeholders. Thus, in the context of IFIs, the Shariah committee is expected to be the gatekeeper of Shari'ah governance and compliance in IFIs for the benefit of all stakeholders and the fulfilment of social obligations.

Inadequate attention given to the effectiveness of the Shariah committee, including its competence and independence, may trigger negative consequences for IFIs, such as massive withdrawals of funds by the public (Ariffin, 2019). A lack of independence can lead to biased judgements, indicating a failure in the monitoring process, which may reduce the quality of reporting. Independence in fact is an underlying principle and necessary for any governance mechanism. The essence of factual independence encompasses the ability and willingness of a person to conquer bias and report honestly (Beattie and Fearnley, 2002). Independence in mind refers to an individual's ability to form an opinion without being affected by any influences that might compromise his/her state of mind in making that opinion. It signifies the state of mind of an individual during his/her decision-making process, which can be influenced by his/her experience, knowledge and relationships and the unique circumstances of the decision at hand. Unlike actual bias, independence in appearance is based entirely on the perception that requires the Shari'ah committee to appear to be independent. Independence in appearance can be described as the avoidance of any circumstances that might cause any reasonable and informed third party to reasonably conclude that the integrity or objectivity of the person is compromised. When those criteria are not met, the person is perceived to be non-independent. Such a perception may be damaging to the IFIs because it would mean that the public would believe that the Shari'ah committee is not truly independent even when that is not the case. Both independence in fact and independence in appearance are important for maintaining professional autonomy and retaining the high esteem in which a profession is held. Any divergence will have negative consequences such as loss of integrity, trust and public confidence which are clearly indispensable to any profession.

Prior studies have discussed the importance of Shariah committee effectiveness and independence, which constitute two of the several challenges faced by Shari'ah committee members in carrying out their fiduciary duties independently (i.e. Garas, 2012; Haridan et al., 2018; Hassan, 2012; Kassim et al., 2016; Mohamad et al., 2015; Ullah et al., 2016). These studies have shown that the undue influence of management, the source of remuneration, limited access to information, the holding of multiple directorships, high reliance on the internal compliance unit and limited authority, to name a few, are some of the factors that may impair the independence of the Shari'ah committee. Mohamad et al. (2015) raised a concern that the Shari'ah committee in Malaysia is remunerated by the IFIs. This situation could affect members' judgement and lead to a conflict of interest and ultimately to the legitimisation of unlawful or dubious operations (Mohamad et al., 2015). Indeed, it has been shown that the independence in appearance of the Shari'ah committee is perceived to be impaired based on the way they are paid because they mostly receive remuneration directly by the IFIs
Independence of the Shari'ah committee 
AJAR

6,2

200

(Ahmad and Al-Aidaros, 2015). Hence, there is a potential conflict of interest, and this might influence their credibility in making judgements. Sori et al. (2015) stated that the impairment of independence perhaps occurred due to personal interests such as keeping a position and continuously receiving a remuneration package (i.e. fees and allowances). Thus, the objective mind of the committee members is at stake because it is difficult to control and observe their state of mind. Mohamad et al. (2015) also highlighted the issue of Shariah committee members holding more than one directorship in more than one IFI, which raised a concern about confidentiality issues as well as having enough time to prepare for meetings. In the case of multiple appointments, the Shariah committee members must engage in proper time management to ensure that they have a strong commitment in preparing and attending the meetings of the respective IFIs in which they hold directorships. This is consistent with an earlier study by Hasan (2014) who highlighted that Shari'ah committee members should limit the number of directorships they hold to mitigate time constraint issues. Also, they should not compromise and breach the confidentiality of sensitive information about different and competing IFIs. Moreover, multiple appointments also allowed the members to enquire fatwas around (Mohamad et al, 2015).

Furthermore, Shari'ah committee members were also found to perform ceremonial roles rather than fulfilling vigilant monitoring roles. This finding supported the earlier studies by Hassan (2012) and Ullah et al. (2016) who documented that Shari'ah committee members play a limited role in promoting religious principles because the management attempts to dictate the decisions made by them. Also, Ullah et al. (2016) highlighted that the management of some IFIs do not uphold Islamic principles and attempt to avoid the supervisory role of the Shari'ah committee. In addition, the management might want to align their performance, profit targets and expected rewards with actual bank performance (Mohamad and Sori, 2016). Hence, the management might exert pressure on the Shariah committee to make decisions in favour of the business rather than Shari'ah requirements because IFIs expend a lot of resources to develop products and services (Sori et al., 2015). A few studies also highlighted the high reliance of Shari'ah committee members on the internal compliance unit in providing Shariah assurance, which triggers concern regarding the issue of independence (Al Mannai and Ahmed, 2018; Haridan et al, 2018). Haridan et al. (2018) revealed that the Shari'ah committee in two IFIs in Malaysia delegates the Shariah compliance review function to internal officers and requests the officers to present the findings to them for approval. This finding supports the study conducted in the Gulf Cooperation Council region, which found that the Shari'ah Supervisory Board relies heavily on the work of the Shari'ah team in IFIs and bases its opinion on internal Shariah review reports (Al Mannai and Ahmed, 2018). This practice obviously implies a problem with the issue of independence.

Next, Kassim et al. (2016) argued that Shari'ah committee members have limited authority in providing assurance on Shari'ah compliance. While, Sori et al. (2015) documented that Shariah committee members hardly participated in the voting process during board of directors or audit committee meetings because they were only invitees. This is further supported by Mohamad et al. (2015) who found that Shari'ah committee members are not invited to attend board meetings even though the meetings may include discussions on Shariah-related matters. Preceding studies indicate that there is limited recognition of the position and role of Shari'ah committee members. They should be able to actively participate in the meetings and provide objective decisions in order to ensure that all the activities of IFIs are in compliance with Shari'ah rather than just being involved in the product approval stage (Kassim et al., 2016). A Shari'ah scholar is a person with a good reputation and character who possesses the necessary qualifications and expertise, particularly in fiqh muamalah and Islamic jurisprudence, and has experience of and/or exposure to Islamic finance (Noordin and Kasim, 2019). Ultimately, it helps to bring greater public confidence in IFIs. In short, there is 
still limited research on the issues related to Shari'ah committee independence in reality and particularly the safeguard measures exercised by Shari'ah committee members in upholding the independence requirements.
Independence of the Shari'ah committee

\section{Method}

A qualitative research approach was employed to achieve the objective of this study to determine "what" the real issues are and to find out "how" to safeguard against the challenges faced in order to uphold independence. Yin (2011) stated that interviews provide a qualitative method of gathering deeper and richer information. In order to gather opinions and views for this research, a face-to-face qualitative interview and semi-structured questions were employed to solicit information from 13 participants of 13 different IFIs. All the interviewed respondents are members of the Shari'ah committee of different IFIs because the study's aim was to explore practices in different IFIs. The respondents consisted of 11 Shari'ah scholars and two non-Shari'ah scholars. Shari'ah committee members would be the most appropriate candidates to gather first-hand information pertaining to the actual issues they encounter and how they utilise safeguard measures to overcome the issues they face in upholding their independence in reality. Interviews were conducted until data redundancy occurred in the subsequent interviews, and data saturation was reached. The interviews were conducted between March and August 2019. In terms of context, SGPD 2019 was being issued in 2019, coming into effect in April 2020 and applicable to all 33 licensed IFIs in Malaysia. The interview was not conducted with strict formality, as stated by (Shaw, 1998), in order to provide a lively and conversational interview session (Shaw, 1998). The interview lasted for about $45 \mathrm{~min}$ to two hours and was audio-recorded. The qualitative data from the interview were then validated through the series of steps suggested by Creswell (2009). First, the recorded interview was transcribed, and the transcription was then analysed using the Atlas.ti software. The participants were also coded for anonymity. The data were read and reread for emerging themes and concepts. These were then matched to the categories as prescribed by the interview questions. The data were analysed based on the within-case and cross-case approaches, and the results of these analyses were then summarised and pattern coded (Hubberman and Miles, 1994). Pattern coding is a way of grouping summaries into a smaller number of sets, themes or constructs. This method was applied because it enables the reorganisation and condensation of the vast array of initial analytic details from the interview into the main output. The results of this process are presented in accordance with respective themes in the following section.

\section{Findings and discussion}

This study examined "what" and "how" issues related to independence are handled by Shari'ah committee members in order to discharge their fiduciary duties in actual practice. The results of the analysis are aligned to the independence requirements in SGF 2010 and SGPD 2019 as well as the prior literature and are elaborated under four significant themes (subsection 4.1 to 4.4), namely (1) Undue management influence; (2) Multiple appointments; (3) Financial reliance and (4) Tenure. Then, based on the evidence obtained by this study, the safeguard measures practised by the IFIs and the Shari'ah committee members in order to uphold the independence requirements are summarised in the final subsection 4.5.

\subsection{Undue management influence}

SGPD 2019 clearly states that the board and management should not have any undue influence on the deliberation and decision-making process during the meetings of the Shari'ah committee. As stated by SC1, the Shari'ah committee's decision should not be 
AJAR

6,2

202

influenced by the consideration of business performance and profit motive; rather, it should be driven by faith-based decisions in line with the requirements of Shari'ah principles. In this regard, SC6 also claimed the following:

SC6: ... . management said that the SC [the Shari'ah committee] needed to approve [a product/service] today so that the bank could offer it next week. No way! We (SC) did not approve it because the documents are not adequate. There were also many Shari'ah issues in the agreement. So to defend [our position], we say, this will affect Islamic banking and affect us, we do not want to affect your business, and we are not aiming to affect your business, but if it does not comply, we will be fair, at the end of the day the Central Bank [BNM] will come looking for us, not for the business banking department.

Based on the above, the Shariah committee members strongly believed that they must uphold Shariah integrity and firmness by sticking to their decisions and not simply going along with the demands of the management whose sole aim is to attempt to achieve profit targets and high performance. The findings also echoed those in the study of Sori et al. (2015), which stated that the Shari'ah committee normally will not tolerate the top management's obsession with achieving their targets and will not submit to pressure. This is in line with the requirements of SGPD 2019, as mentioned by SC3:

SC3: ... the Shari'ah committee usually will be seen as representing shareholders ... . because this is how the Shari'ah board is set up for example in full-fledged banks where in that sense they present their report to the shareholders.

Furthermore, SGPD 2019 requires that any decisions made by the Shari'ah committee are based on an informed judgement, and that all the required information is adequately furnished by the management. The chairman of the Shari'ah committee also should fulfil his role in controlling the flow of the meeting to avoid any unnecessary influences being forced upon the committee by the management, board or even the secretariat. Besides, all Shari'ah committee members are allowed to freely discuss and advise on matters and issues that are tabled in the meetings, which supported by SC7:

SC7: [There is] no influence as everyone is equally given a chance, highly independent, the chairman is lenient and has no influence.

\subsection{Multiple appointments}

The holding of multiple appointments in different organisations should be taken into consideration due to the possibility of situations arising that might lead to a conflict of interest and that might also affect the readiness of Shari'ah committee members in terms of preparing for and attending meetings (BNM, 2019; Hasan, 2014; Mohamad and Sori, 2016). Shariah committee members must be able to balance their daily duties, other commitments and additional tasks associated with their role as Shari'ah committee members in order to devote sufficient time to being fully prepared for meetings. Notably, lack of preparation for meetings would have an impact on the performance in deliberating the facts due to being limited time to do additional research or searches for information or due to misunderstanding the facts contained in the minutes of meetings. In this regard, SC4 claimed the following:

SC4:[D]ifferent individuals have different kind of thoughts and different kinds of perceptions of how they do their work. We are not trying to blame the Shari'ah committee for not performing their duties even though they are busy.

Furthermore, as asserted by Mohamad et al. (2015), the rapid growth of the Islamic finance industry may have increased the demand for a greater pool of more-qualified Shariah scholars, particularly with the expansion of demand in other Islamic institutions and the halal 
industry sector (Saad and Rahman, 2018). The capability of the members to manage their time when they are on many committees at one time also needs to be looked at. Moreover, confidentiality due to greater exposure to relative information needs to be observed by the members of the Shari'ah committee too, and there are two sides to this coin, as explained by $\mathrm{SC} 1$ and SC9:

SC1: ...that's a lot [of information], at least one email per day and one email sometimes contains a lot of documents and may include an attachment that extends to 100 pages such as manuals and other documentation. So, I tend to disagree with some of the scholars or some of the public's perception that being a Shari'ah committee member is only a part-time job. It is actually a full-time job, though the burden and responsibility are much heavier than that. . .

SC9: Being on many committees allows for more exposure, more experience because different organisations have different issues, different approaches.

\subsection{Financial reliance}

Reliance on financial remuneration may jeopardise the independence in appearance of the Shari'ah committee as their remuneration is paid by the bank, which results in a direct relationship between the bank and the Shari'ah committee (Mohamad et al., 2015). The appointment as a Shari'ah committee member should be treated as a profession rather than an occupation. As such, individuals on the committee should uphold a high level of professionalism in delivering the required expertise and reduce their dependency on the remunerations received in order to eliminate any conflict of interest. Thus, a Shariah committee member should not rely on the remuneration from the bank(s) for personal consumption or their level of commitment to their duties, as elaborated by SC1:

SC1: So that from the very beginning I am ready to be terminated anytime, so that I have no conflict of interest. This is how I protect myself from dependency on the bank, and I do not use the money from the bank to support my daily needs.

In contrast, SC9 argued that the remuneration should compensate for the amount of work done or that was required to be achieved or delivered. The level of commitment from the Shari'ah committee members was highly regarded by the banks because the committee members have to do some work and research in order to prepare for meetings. Hence, it was fair enough to pay for their time and effort in discharging their obligated duties. According to SC9,

SC9: If they [the banks] pay less, then the Shariah committee will show less commitment.... obligation you know and commitment. You have to do research, sometimes we ask them to conduct training for us but they do not do anything, they are reluctant to do so.

\subsection{Tenure}

SGF 2010 and SGPD 2019 strongly emphasise the importance of appointing a person with an acceptable reputation, character and integrity (BNM, 2010, 2019). In the context of persons those charge with governance, having such attributes is pertinent so as to ensure the quality of the judgements and decisions made. In a similar vein, the respondents indicated that having such attitudes, like firmness and strictness, would give a strong signal to the management about the seriousness of the Shari'ah committee in handling all matters related to Shari'ah compliance. As such, the Shari'ah committee members would not be afraid of telling the truth even if what they said might be disliked by the respective banks and even though it might affect their renewal or reappointment as Shari'ah committee members. As pointed out by SC5, 
AJAR

6,2
SC5: I think things [get] bounced back to us and we need to have principles. So, for me regardless of whether there are things that will affect my position here, he wants to renew or not, my duty is to say what is supposed to be said is. . It depends on the people that have individual principles.

SC6: [W] do not care if the bank does not want to renew us. . . . but in my understanding, when we are in this bank, we are strict.

Furthermore, independent Shari'ah committee members should not be concerned about or even hedge their bets to ensure their tenure renewal. This is consistent with the study of Sori et al. (2015) which stated that Shari'ah committee members may not be aware of their own conflicts of interest in dealing with personal interests. According to SC1,

SC1: The Shari'ah committee should not have to compromise on its decision just to be very lenient to ensure that their contract is renewed. ... Although we are paid by the management, by the bank, our KPIs [key performance indicators] are on us ...., this is to avoid conflict of interest. It is very difficult you see to be very independent at the banking level especially when you are part of the management. You are paid by the bank but at the same time you are just [there] to find the mistakes made by the bank, that's why sometimes the Shari'ah committee [members face a] dilemma when they sit in [a board] meeting as to whether they have to speak for the Shari'ah committee or against the Shari'ah committee. The Framework is clear [it is the responsibility of the bank] to support the Shariah committee, to provide the necessary input and information and data for the Shariah committee.

In addition, the Shariah committee members stated that their length of service on the committee would not jeopardise the extent of their independence. The role of the Shariah committee is to ensure that all the business activities and operations of the bank are in compliance with Shari'ah principles. This is in contrast to board members, who have to indulge and make decisions in relation to the overall operations and directions of the bank. According to SC3 and SC4,

SC3: Apparently, [the issue of] familiarity does not apply to the Shari'ah committee. [But it does apply] to the board, why? I think the board is more operational. ... This Shari'ah committee is more developmental, so [this issue of] familiarity may not be as [crucial as it is] for the board.

SC4: But the longer I am at this bank the more independent I am. At first, it's kind of not independent, it's that we are kind of afraid, but again we soon get to know how the banking system operates.

Moreover, due to a limited pool of resources, the secretariat sometimes has difficulties in finding good Shariah committee candidates. With the support of continuous training, committee members can be well-equipped in terms of having the relevant knowledge and awareness of developments in the sector, which any newly appointed members might require some time to learn especially due to the complexity of IFI operations. In regard to the above, SC8 and SC4 stated the following:

SC8: [B]ecause even now when we look at the Shari'ah committee, exchanges of members do not occur very often.

SC4: [A]11 the Shari'ah committee members need to learn as you are not a banker but you are in the bank to advise the banking operation. You have to know how banking operates. You must have the mentality, like a willingness to learn.

\subsection{Safeguard measures}

The preceding sections discussed the presence of key issues that may impair the independence in fact and independence in appearance of the Shari'ah committee members in discharging their fiduciary duties effectively. Echoing the prior literature, the insights from this study also underline the importance of personal character, competence, the role of the chairman of the Shari'ah committee and the sense of accountability exercised by the Shari'ah 
committee members as safeguard measures to uphold objective mind and independence in appearance.

Personal character: Notably, every appointment of a committee member is based on his/ her personal character and integrity and attributes that are often assessed by the BNM. The underlying principle is that the person must uphold an objective mind, and most of the time the ability to do so is influenced by the personal characteristics, competence and experience of the respective Shari'ah committee members, as asserted by SC9 and SC7:

SC9: ... personality affects the role played by the person in performing as a Shariah committee member.

SC7: As she [a Shari'ah committee member] is a strict person she would often stick to her opinions especially when there were reasonable doubts. She always played the role of "devil's advocate", as she preferred to have proper rules in place in order to cover "what if such-and-such a situation happens". This is very much in line with her legal background where she takes a comprehensive view and always ensures that all the provisions and clauses are inserted in the agreement.

The notion for committee members to be of good character is confirmed by Noordin and Kasim (2019) that personal characteristics such as integrity and ability to be firm or strict are highly considered when nominating a candidate. Evidently, the results of the current study highlight that the undue influence of management could be hindered through having a strong personal character like integrity and firmness. Moreover, in order to demonstrate a high level of independence, the person should have good objectives and reasons for becoming a committee member as this would also reduce his/her dependency on the financial remuneration given by the IFIs.

Competence and accountability: The findings also showed the Shariah committee members who had adequate and relevant competencies were more knowledgeable and wellinformed on the latest banking activities, which would definitely facilitate objective decisionmaking. This is exemplified by the comments of SC8 and SC6:

SC8: Everybody brings out their own experience as sometimes even we cannot foresee that something may be an issue unless other members maybe highlight that it is an issue, that's why we need to discuss and deliberate and decide later.

SC6: Knowledge in Shari'ah is required and other knowledge as well such as business, industry and legal, because there are plenty of product agreements presented by legal or management that need to be seen to become familiar with the terms.

As indicated by Noordin and Kasim (2019), the importance of being able to refer issues to qualified Shari'ah scholars in the area of Islamic figh muamalah and Islamic finance is greatly expected in order to boost public confidence. Accountability to God and legislative requirements further improve the commitment among the Shariah committee members to observe the need to have a high degree of independence, which is in line with the study of Abdul Rahman and Bukair (2013).

Chairman's role: The chairman of the Shariah committee generally ensures the proper conducts of meetings, which is one of his most valuable contributions to the organisation. The chairman's personality may influence such conduct through his ability to exert a powerful influence while at the same time retaining collegiality and a team spirit in making sound decisions (Lechem, 2003). Additionally, the findings of the current study also highlight that the chairman should play his role assiduously to ensure the presence of independence and objective mind in the meetings and no obvious group influence among members during the argumentation and judgement-making process. Moreover, in the context of IFIs, the chairman should practise Shura in the meeting and act as a catalyst to preserve the interest of all stakeholders and achieve social justice and welfare within the 
AJAR

6,2

206

community. These findings are supported by the claims made by several Shariah committee members:

SC8: Being a chairman, first you have to join the meeting and control the running of the meeting and then [you have tackle how] to get the opinion from other members as well as how to control the timing of the meeting so that you can come out with the solution at the end of the meeting or during the targeted time.

SC6: The chairman will deliberate and clarify so that others will be able to see too... I think the chairman plays an important role ... and he needs to know everything about operations.

SC8: We know that the member is qualified and knowledgeable, but he might not be able to share his knowledge. So that's why in the discussion, the chairman has to play his role.... as the chairman has the right to put questions to everyone in a certain manner.

Board engagement: Another factor that needs to be revisited is the process of engagement between the members of the Shari'ah committee and the board due to the unique governance structure of IFIs. Board engagement refers to the time spent by the board members in actively engaging with the Shari'ah committee members in the form of dialogue to explore pertinent Shariah issues concerning IFIs. The insights obtained indicate that an increase in board engagement activities could promote trusting relationships and a sense of authority which would improve the governance and performance of IFIs. The nature of board engagement may vary from one IFI to another, and it could possibly be conducted in formal or informal ways, as reflected in the following claims:

$\mathrm{SC1}$ : The chairman or member of the Shari'ah committee serves as an independent executive board member, a permanent member, who joins board meetings similar to board members. First, it is an advantage to have a committee member as a member of the board, because the board can easily be updated on any Shari'ah decision. Second, having a Shari'ah committee member on the board puts both at par as there is no sense of one being superior and one being inferior, hence we can present [the opinions of our committee] confidently.

SC2: Not even board members or the CEO attend SC [Shari'ah committee] meetings because this bank is an (Islamic) window and not fully subsidiary. A window is not even one hand but business of Islamic window is only one finger in the (whole) business.

Arguably, the board members must invest sufficient time and energy to understand the risks to which their IFIs are exposed. The engagement between the members of the board and the Shari'ah committee may even allow the exploration of the perspectives of prominent scholars who understand global trends in Islamic finance and different fatwas. Mohamad et al. (2015) confirmed this notion by stating that board engagement may reduce the gap and raise the bar for both parties, as they both gather useful information in the form that works best for them.

In a nutshell, safeguard measures are undertaken by the Shari'ah committee to ensure the good practice of independence and the ability to provide sound and informed judgements. The Shari'ah committee acts as a mechanism to strengthen the oversight of Shariah compliance. Therefore, an argument that the establishment of stronger Shariah committees can discharge their monitoring role more effectively will heighten public confidence and protect the legality of the products and services offered by IFIs (Hasan, 2014). In order to discharge their fiduciary duties and responsibilities, it is crucial that Shariah committee members have both independence and competence (Almannai and Ahmed, 2018). This is in line with accountability theory from the Islamic perspective as well as agency theory.

\section{Conclusion, implications, limitations and future research}

Independence is a crucial attribute as it allows Shariah committee members to perform their roles and responsibilities in monitoring and advising on Shari'ah compliance effectively. 
This study gathered perceptions from the Shariah committee members with regard to the concept of independence in practice. The results indicated that, from their perspective, several circumstances would impair their independence such as the undue influence of management and the holding of multiple positions, length of tenure and financial reliance. On the other hand, the findings highlighted that several safeguard measures were exercised by the Shariah committee members. These measures involved the personal character and competence of the committee members themselves, the role of the chairman of the Shariah committee and board engagement.

The insights obtained by this study have a number of important practical implications that led to the development of some specific recommendations on safeguard measures that could be exercised or adopted by Shari'ah committee members to uphold a high level of independence in practical reality. The following considerations need to be revisited in formulating future policies. First, the regulatory body is encouraged to outline guidelines for remuneration in order to adequately compensate the effort, commitment and risk exposure associated with the position of Shari'ah committee members in respective IFIs. The establishment of guidelines for remuneration is highly important because the Shari'ah committee currently has more responsibility and accountability for ensuring that banks are Shari'ah compliant, and IFSA 2013 imposes stringent penalties for noncompliance that also affect the Shari'ah committee. Second, a good mechanism of engagement with the board members is considered to be an alternative way to enhance the recognition and authority of Shari'ah committee members. Frequent engagement would improve the management's understanding of the importance of Shari'ah compliance. Also, board engagement would definitely be a good way for both parties to discuss and strategize on the implementation of the Shari'ah compliance culture that is emphasised in SGPD 2019. Finally, proper explanation on matters related to multiple directorships in the proper and fit criteria section of SGPD 2019 is required. In particular, in line with the growing need for more Shari'ah scholars in other sectors such as Islamic institutions and the halal industry that are not governed or regulated by SGPD 2019, current scholars may be exposed to the risk of holding multiple directorships in IFIs and other organisations in Malaysia and might also include appointments to other Islamic institutions in other countries.

Finally, as regards the limitations of this study, it should be noted that the results do not provide conclusive evidence on the issue of independence in fact and in appearance because the interviews that were conducted, focused on the perspective of Shariah committee members only. This implies that further research is needed to look at this issue more holistically by obtaining inputs and insights from other stakeholders such as the Shariah secretariat and management as it may provide a different perspective. Similar research in the past have mainly derived their findings from data obtained based on the perspective of the board of directors.

\section{References}

Abdul Rahman, A. and Bukair, A.A. (2013), "The influence of the shari'ah supervision board on corporate social responsibility disclosure by Islamic banks of Gulf cooperation council countries", Asian Journal of Business and Accounting, Vol. 6 No. 2, p. 65.

Ahmad, M.R. and Al-Aidaros, A.H. (2015), "The need of independent shari'ah members in Islamic cooperative banks: an empirical study of professional accountants in Malaysia”, International Review of Management and Business Research, Vol. 4 No. 1, p. 110.

Al Mannai, M. and Ahmed, H. (2018), "Exploring the workings of the Shari'ah supervisory board in Islamic finance: a perspective of Shariah scholars from GCC", The Quarterly Review of Economics and Finance, Vol. 74, pp. 97-108.

Independence of the Shari'ah committee 
AJAR

6,2

Alnasser, S.A.S. and Muhammed, J. (2012), "Introduction to corporate governance from Islamic perspective”, Humanomics, Vol. 28 No. 3, pp. 220-231.

Ariffin, M.Y. (2019), "Better governance with new Islamic finance framework", New Straits Times, available at: https://www.nst.com.my/opinion/columnists/2019/10/527150/better-governancenew-islamic-finance-framework.

Bank Negara Malaysia (2010), Shari'ah Governance Framework for Islamic Financial Institutions, Kuala Lumpur, available at: http://www.bnm.gov.my/ (accessed 24th January 2019).

Bank Negara Malaysia (2019), Shari'ah Governance Policy Document, Kuala Lumpur, available at: http://www.bnm.gov.my/index.php? (accessed 15th October 2019).

Beattie, V. and Fearnley, S. (2002), Auditor Independence and Non-audit Services: A Literature Review, Institute of Chartered Accountants in England and Wales, London.

Creswell, J.W. (2009), Qualitative Inquiry and Research Design: Choosing Among Five Approaches, 3rd ed., Sage Publications, CA.

Garas, S.N. (2012), "The conflicts of interest inside the Shari'a supervisory board", International Journal of Islamic and Middle Eastern Finance and Management, Vol. 5 No. 2, pp. 88-105.

Haridan, N.M., Hassan, A.F.S. and Karbhari, Y. (2018), "Governance, religious assurance and Islamic banks: do Shari'ah boards effectively serve?”, Journal of Management and Governance, Vol. 22 No. 4, pp. 1015-1043.

Hasan, Z. (2014), "In search of the perceptions of the Shari'ah scholars on Shariah governance system", International Journal of Islamic and Middle Eastern Finance and Management, Vol. 7 No. 1, pp. 22-36.

Hassan, A.F.S. (2012), An Empirical Investigation into the Role, Independence and Effectiveness of Shari'ah Boards in the Malaysian Islamic Banking Industry, PhD Thesis, University of Cardiff.

Hubberman, A.M. and Miles, M.B. (1994), Qualitative Data Analysis, Sage, Beverly Hills.

Kassim, N., Hashim, N.A. and Salman, S.A. (2016), "Conceptual relationship between corporate governance and audit quality in Shari'ah compliance companies listed on Bursa Malaysia", Modern Applied Science, Vol. 10 No. 7, pp. 106-114.

Lechem, B. (2003), Chairman of the Board: A Practical Guide, John Wiley and Sons, Chicago.

Mohamad, S. and Sori, Z.M. (2016), "Effectiveness of shariah committees in the Malaysian Islamic financial institutions: the practical perspective", MEI Insight IFS, Vol. 2, pp. 1-8.

Mohamad, S., Sori, Z.M. and Shah, E. (2015), "Shari'ah governance: effectiveness of Shariah committees in Islamic banks in Malaysia", SSRN Electric Journal. doi: 10.2139/ssrn.2579174.

Mohammed, S.A.S.A.N. and Muhammed, J. (2017), "The relationship between agency theory, stakeholder theory and Shariah supervisory board in Islamic banking", Humanomics, Vol. 33 No. 1, pp. 75-83.

Noordin, N.H. and Kassim, S. (2019), "Does Shariah committee composition influence Shariah governance disclosure?", Journal of Islamic Accounting and Business Research, Vol. 10 No. 2, pp. 158-184.

Saad, S.N.H. and Rahman, F.A. (2018), "Optimizing the role and responsibility of the Shariah committee: from Islamic finance to the halal industry", Proceedings of the 3rd International Halal Conference (INHAC 2016), Springer, pp. 299-313.

Shaw, E. (1998), "A guide to the qualitative research process: evidence from a small firm study", Qualitative Market Research: An International Journal, Vol. 2 No. 2, pp. 59-70.

Sori, Z.M., Mohamad, S. and Shah, E. (2015), “Shari'ah committee independence: an insider's view”, Research Bulletin, Vol. 6, available at: http://www.inceif.org/research-bulletin/Shari'ahcommittee-independence-insiders-view/.

Ullah, S., Harwood, I.A. and Jamali, D. (2016), "Fatwa repositioning': the hidden struggle for Shari'a compliance within Islamic financial institutions", Journal of Business Ethics. doi: 10.1007/ s10551-016-3090-1.

Yin, R.K. (2011), Qualitative Research from Start to Finish, The Guilford Press, New York, NY. 


\section{Further reading}

Akhtar, S. (2006), "Syariah compliant corporate governance", Keynote Address by the Governor of the State Bank of Pakistan at the Annual Corporate Governance Conference, Dubai, pp. 243-83.

Al-Safi, A.K. (1992), Accountability: Islam versus the Man-Made Doctrines, Darulfikr, Kuala Lumpur.

Hasan, Z. (2011), "A survey on Shariah governance practices in Malaysia, GCC countries and the UK: critical appraisal", International Journal of Islamic and Middle Eastern Finance and Management, Vol. 4 No. 1, pp. 30-51.

Muhamad, R. (2011), "Shari'ah compliance process and corporate governance in Islamic banking institutions (IBIs): a proposed model”, Journal of Accounting Perspectives, Vol. 4, pp. 36-48.

Raman, A.A. and Bukair, A.A. (2013), "The influence of the Shariah supervision board on corporate social responsibility disclosure by Islamic banks of Gulf cooperation council countries", Asian Journal of Business and Accounting, Vol. 6 No. 2, pp. 69-91.

\section{Corresponding author}

Nor Hafizah Zainal Abidin can be contacted at: nhafizah@iium.edu.my
Independence of the Shariah committee

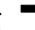

